\title{
7 No Support for Anti-Bolshevist Emma
}

In a letter to her then lover and manager Ben Reitman, supposedly written in 1914, Emma Goldman described herself as "the fighter, the warrior, the woman battling against a thousand odds" who also shared "elemental love and passion" " with those who shared life and bed with her. With her works about Soviet Russia, which were discussed in some detail in the previous chapter, Goldman caused a storm of outrage directed against her views that would demand much courage from the self-described anarchist "fighter" to resist the wish to simply cry and get lost in eternal sadness, as the accusations she had to face since the early 1920 s were more than an ordinary human being could easily take. Yet Goldman fought, Goldman never gave up, and Goldman repeated her accusations against Bolshevism, her descriptions of Soviet Russia, and her evaluation that the Russian Revolution had been betrayed by Lenin and his followers. She consequently remained "the woman battling against a thousand odds" during her exile years, although it was not easy for her to accept her isolation in the fight for the truth about Soviet Russia to be heard.

Goldman might have felt such isolation before, be it in her relations with the US press when the "newspapers ha[d] completely boycotted" the famous anarchist, or in her personal relationships, e.g. in her toxic relationship with Ben Reitman, who was "born to be a manager" and hence was "not born to love [Goldman]." When Goldman had started her anti-Bolshevist crusade in January 1922, it was hard for her to find allies, although the things she described seemed more than obvious and therefore reasonable, especially to herself: "Now in the face of overwhelming evidence of cruellest oppression and persecution in Russia, the world remains silent and callous. The heroic martyrs are left to the tender mercies of the Tchecka, to suffer the Golgotha of the body as well as of the spirit, in the name of an ideal that has long since been betrayed by the Communist State and its Party dictatorship." 3 She would repeat similar statements in her lectures, in her publications, and in her letters to comrades and friends, but Goldman seemed unable to actually persuade anyone to take a stand against the Bolsheviki who ruled Soviet Russia and later the Soviet Union. The radical intellectuals of the world seemed unwilling after 1917 to criticize the corruption of the Russian Revolution too openly, maybe because some of them feared to discredit the idea of a revolution once and for all, or maybe because others were still will-

1 Emma Goldman Letter to Ben Reitman, n.d. [1914], EGP-IISH, No. 132, 1.

2 Emma Goldman Letter to Ben Reitman, Denver, July 13, 1916, EGP-IISH, No. 132, 2.

3 Emma Goldman, Heroic Women of the Russian Revolution, EGP-IISH, No. 221, 5.

2 OpenAccess. () 2020 Frank Jacob, published by De Gruyter. (cc) BY-NC-ND This work is licensed under the Creative Commons Attribution-NonCommercial-NoDerivatives 4.0 License.

https://doi.org/10.1515/9783110679403-007 
ing to believe that the Russian Revolution had actually achieved and fulfilled a social change that had only been utopian before. Nevertheless, for Goldman, the years after 1922, like her whole life, as she later confessed in a letter to Arthur Ross on 30 December 1933, "had been nothing else but a test of patience and endurance." ${ }^{4}$ In her public lectures, however, she would not admit this, and she continued to explain true anarchism and how the Lenin and the Bolsheviki had destroyed the Russian Revolution, betrayed the Russian people, and corrupted their revolutionary ideals since the Red October of 1917.

Due to events related to the Russian Revolution, Goldman would, in her lecture notes for "Anarchism and What it Really Stands For,"5 naturally also reflect on the modern phenomenon of revolution from an anarchist perspective. In her notes, which were a continuation of her text from 1910 by the same title, ${ }^{6}$ she argued that "[i]t is in the interest of those who hold power to keep the delusion that the state, law, and government had originated in the need of protecting the weak against the strong" and that "the state originated in conquest and confiscation, as a device for maintaining the stratification of society permanently into two classes: an owning and exploiting class, relatively small, and a propertyless class."7 An anarchist would consequently have to resist any attempt to establish a state rule, as it would only be erected to suppress the masses of the people and individual freedom alike. Anarchism, in contrast to any other political philosophy, consequently, as Goldman continued in her reflection, "is the only social philosophy that maintains that there never has, or could be, a human being or a group of men so all knowing and wise to fathom that [sic!] what is to be the best interest of another. Nor should they be placed in a position that would give them the might to coerce others to their wisdom."8 An anarchist would also have to carefully resist any form of hierarchy, as "[p]ower over others corrupts, brutalises and destroys the sense of proportion. It makes for conflict, strife and disintegration." ${ }^{9}$ Consequently, no anarchist could support Bolshevism:

4 Emma Goldman to Arthur Ross, Toronto, December 30, 1933, EGP-TAM, Box 1, Emma Goldman Correspondence to Arthur Ross, Jan. 4, 1933 - Dec. 30, 1933, 1.

5 Emma Goldman, Anarchism and What It Really Stands For, n.d., EGP-IISH, No. 191.

6 Emma Goldman, Anarchism and Other Essays (New York: Mother Earth, 1910). Accessed May 20, 2020, https://theanarchistlibrary.org/library/emma-goldman-anarchism-and-other-essays\# toc3, ch. 1 .

7 Goldman, Anarchism and What It Really Stands For,3.

8 Ibid., 5.

9 Ibid., $5^{1 / 2}$. 
Truth is every Anarchist is also a socialist, because he recognizes the imperative need of the socialization of the land, and the means of production and distribution. Certainly we Anarchists go further than the Marxian adherents. For we insist on SOCIALIZATION, NOT NATIONALIZATION OF NATURAL RESOURCES. ... [F] or this reason we insist that it matters little whether the balance of economic power is in the hand of a private individual, or as it is today in the hands of rugged individualism, or in the hands of the Socialist State, or under the Dictatorship of the Proletariat. All need and use the machinery of government to impose their will on others to coerce those who cannot and will not submit to their regime. ${ }^{10}$

The Russian Revolution, or more accurately what Lenin had turned the February Revolution of 1917 into, was nothing revolutionary anymore, as "the masses have grown to believe in the sanctity of tyranny, they have become voluntary slaves. Habit is indeed the most vicious slave driver."11 In her reflection, Goldman tried to give an idea of the history of anarchism from antiquity to modernity, but it is, of course, more than obvious what role the corruption of the Russian Revolution played in Goldman's perception and interpretation of Marxist communism and Leninist Bolshevism.

For Goldman, it was Lenin who had betrayed the Russian people and "unmade the Revolution." ${ }^{12}$ He may have supported the masses and the revolution at one point, but "[h]is aim, however, was something quite separate and distinct from the aims of the people. It was the Marxian State-a formidable, all inclusive, all absorbing, all crushing machine-with Lenin and his party at its helm." ${ }^{13}$ His time would come in 1917, "[w]hen the revolutionary waves swept Lenin into Power, his hour had come-the hour to realise his dream. Not even his bitterest enemies can say that Lenin ever stopped at anything to achieve his aim." ${ }^{14}$ He then made it possible for the Marxist state to emerge "out of the blood and ashes of the great beginning"15 and, by doing this, sacrificed the alliances with those forces that had helped him to achieve power. Lenin turned against anarchists and Social Revolutionaries alike and filled Soviet prisons with his former comrades together with anyone else who was brave enough to openly criticize the developments under the Bolshevist rule. For Goldman, Lenin was consequently corrupt through and through: "Largeness of spirit, generosity of heart, understanding for and compassion with an opponent, were utterly lacking in the man who was yet so very human in errors and often criminal

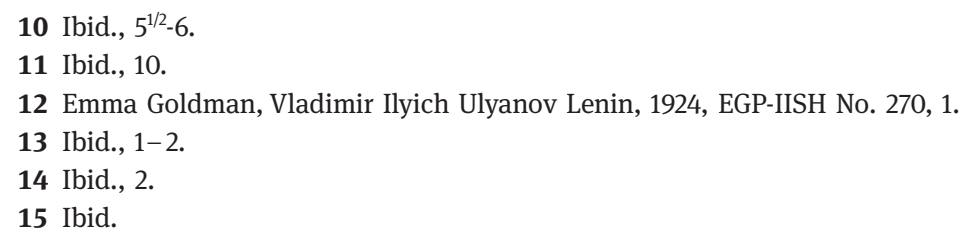


blunders." ${ }^{16}$ Although one could critically discuss if Lenin had planned to corrupt the revolution or if he acted out of multiple necessities to do so due to international interventions or the Russian Civil War, for Goldman, it was clear that the Bolshevist leader had acted purposefully to corrupt it.

From her point of view, "Lenin had greatness, but it was the greatness of Jesuitism, the will to cunning, to unscrupulousness, and an utter disregard for the stupendous sacrifice brought to the altar of his Deity."17 With his actions since October 1917, he had proved to be "reactionary" and that his policies were a consequence of "his counter-revolutionary inclinations." ${ }^{18}$ It was the Cheka that had "turned Russia into a human slaughterhouse," the New Economic Policy was nothing more than a "reintroduction of Capitalism," and, all in all, it was "not only Russia, the whole world has paid for the Jesuitism of Lenin, for it has disintegrated the ranks of the oppressed everywhere." ${ }^{19}$ Goldman, who would live longer than Lenin, would also witness the dangerous consequences of the latter's policies, which would lead to more sorrow and suffering in the Soviet Union in the years after his death: "Lenin injected a dangerous poison in the ranks of the proletariat. Gradually, his own ranks were infected by it. So long as Lenin held the Bolshevik scepter, nothing was permitted to come to the surface. Now, when death itself has relaxed the iron hold, the poisons so long dammed up, have rushed forth, and is threatening to engulf the whole edifice so painfully built up by the great Jesuit of modern times. ... The Revolution is dead. Long live Leninism!"20

Goldman would repeat these statements again and again, but since she had left Bolshevist Russia in December 1921, it was hard for her to find an audience, whether in Europe or in the United States. The current chapter will present these problems that the famous anarchist had to deal with during the 1920s. It will therefore take a look at Goldman's time and activities in Britain, where she failed to gain attention and support in different forms, before taking a look at her struggle with American intellectuals, who obviously did not seem to be interested in the things the famous anarchist had to say about Bolshevism. It is impressive that Goldman, regardless of all the criticism she received, never gave up her crusade for freedom in a time when nobody wanted to see or believe her argument that the Russian Revolution had been betrayed by some of the people that had been central to it during its foundational process.

16 Ibid.

17 Ibid., 4.

18 Ibid.

19 Ibid.

20 Ibid., 5-6. 
In Britain, the reaction within the national Left towards the events in Russia in 1917, especially after Red October, was enthusiastic, and anarchists and Marxists alike supported the new Soviet government. ${ }^{21}$ Journals like The Spur even defended Bolshevism when anarchists and Social Revolutionaries in Russia began to attack it for having betrayed the revolution. ${ }^{22}$ Considering the pro-Bolshevist standing of many British leftists, Goldman's anti-Bolshevism, which she expressed whenever she had the possibility to do so, must naturally have caused problems for her since she had moved from Berlin to London in September 1924. During a dinner in the English capital, at which important British leftist intellectuals like Rebecca West (1892-1983), Edward Carpenter (1844-1929), Havelock Ellis (1859-1939), Bertrand Russell, H. G. Wells (1866-1946) and Israel Zangwill (1864-1926) participated on 12 November 1924, Goldman delivered a speech that would cause immediate antagonism. ${ }^{23}$ She emphasized that "[i]t took [her] two years in Russia to find out [the] grievous mistake in believing that the ruling power was [an] articulate of the Russian Revolution." ${ }^{24}$ She made clear that it was a mistake to believe that the Bolsheviki would act in the interest of the revolution and that it was unfortunate that Kropotkin had already died: "Alas the Grand old man is no longer with us, and there seems to be no one else of his brain and heart to do what he would most assuredly have done now as he did then, to speak and write against the terror going on in Russia under the new regime." 25 Knowing how hard her position would be to defend, Goldman also clearly expressed that she was ready to counter every criticism and that she would not give up her task to bring the truth to light: "I know I shall be burned in oil by the followers and friends of Moscow, I shall be denounced as a counter revolutionist, in the employ of the Whites. ... [But nothing] can stop me from my determination to articulate the dumb misery and suffering of Russia's politicals."26

The dinner "was a disaster," especially since most attendants had not read Goldman's books before and considered her attitude towards Bolshevist Russia a "betrayal." 27 The famous anarchist would feel her ostracized position even more sharply during the years she spent in Britain and, as Gornick correctly highlight-

21 Martin Durham, "British Revolutionaries and the Suppression of the Left in Lenin's Russia, 1918-1924," Journal of Contemporary History 20, no. 2 (1985): 204.

22 See for example the Spur issues from July and September 1918.

23 Emma Goldman, Speech at Dinner in London, November 12, 1924, IISH-EGP, No. 284.

24 Ibid., 2.

25 Ibid., 3.

26 Ibid.

27 Gornick, Emma Goldman, 118. 
ed, "Now she found herself triply cast out: alienated from an exhausted postwar world in which political activism held no allure; harassed by government authorities who continued to see her as a threat to the state; separated from a weakened European and American left which shrank, repelled, from her denunciation of the Bolsheviks." ${ }^{28}$ It is impressive, and in retrospect even more so, that Goldman did not give up her attitude and was unafraid to touch raw nerves, even if that meant an estrangement with the political Left of her time. The famous anarchist was never known for seeking compromises, and when it came to the betrayal and corruption of the Russian Revolution by the Bolsheviki, Goldman was not willing to move even an inch. For many British radicals, nevertheless, "her analysis of Russia in 1920 and 1921 was so overwhelmingly negative-a blackand-white depiction of what was still only a revolution in trouble." ${ }^{29}$ And the anarchists? The movement had been extremely weakened by the First World War and its consequences and, leaving the history of the Spanish Civil War that also revitalized Goldman one last time to one side, it would take around five decades until anarchism attracted the masses again for a revolutionary fight against capitalism.

Personally, Goldman did not gain a lot from her severe anti-Bolshevist stance, but morally she never gave in and continued to defend her views on and position towards Lenin's and later Stalin's rule. While she and Berkman were unable to revive the anarchist movement in the 1920s, they at least held up anarchist values high and made it possible for the latter to survive during the age of extremes. In the meantime, however, Goldman had to make tremendous changes to her personal life, considering her former emphasis on total individual freedom. To be able to stay in London, the famous anarchist married James Colton, a 65-year-old anarchist and mine worker from Wales, to gain citizenship, albeit for "her least favorite country." ${ }^{30}$ It would take two years in the English cold before Goldman and Berkman bought, with the financial support of Peggy Guggenheim (1898-1979), who would also help finance the anarchist's autobiography, ${ }^{31}$ a cottage in Saint Tropez, where Goldman would begin to work on Living My Life and reflect upon her multiple struggles with authorities of all sorts, states of all kinds, and betrayals on both the professional and personal level.

28 Ibid.

29 Ibid., 120.

30 Ibid., 122.

31 Goldman, Living My Life, Appreciation. On Guggenheim see, among other works, Francine Prose, Peggy Guggenheim: The Shock of the Modern (New Haven, CT: Yale University Press, 2015). 
Before she began her work on her autobiography in France, Goldman continued her anti-Bolshevist crusade during her years in London. The famous anarchist still had hopes of persuading the British leftists of the truth about Bolshevism and what she had seen in Soviet Russia. ${ }^{32}$ Goldman did not omit to mention that "while [she] was never a Bolshevist, [she] yet sincerely believed that the Bolshevists were interpreting the ideals of the Russian people, as registered by them in the Great Russian Revolution,"33 this being a reason she had supported Lenin and his followers during her last two years in the United States. Once she was sure that she would be deported, Goldman "preferred to go to Revolutionary Russia to help in the sublime effort of the people to make the Revolution a living factor in their lives." 34 The famous anarchist could accept that many left intellectuals were still at this point with regard to their attitude towards Bolshevist Russia, which is why it was even more necessary to listen to and understand Goldman's experience, who was shocked by the things she saw during her two years in Soviet Russia:

\footnotetext{
What I actually found was so utterly at variance with what I had anticipated that it seemed like a ghastly dream. I found a small political group ...-the Communist Party-in absolute control ... Labour conscripted, driven to work like chattel-slaves, arrested for the slightest infringement ... the peasants a helpless prey to punitive expeditions and forcible food collection ... the Soviets ... made subservient to the Communist State ... a sinister organisation, known as the "Cheka" (Secret service and executioners of Russia), suppressing thought ... the prisons and concentration camps overcrowded with men and women ... Russia in wreck and ruin, presided over by a bureaucratic State, incompetent and inefficient to reconstruct the country and to help the people realise their high hopes and their great ideals. ${ }^{35}$
}

However, in a letter to Roger Baldwin from 6 November 1924, Goldman made it clear that it was not easy to persuade the British left that these observations of hers were actually true. Too many did not listen, and in the letter she wrote that "[t]he main obstacle will be the confusion and superstition prevalent in England about Russia. In that respect I think it is like America, where Radicals and Liberals alike have been mesmerised by the hypnotic spell of Moscow, or rather by the myth foisted upon the world by Moscow."36 Bolshevism was "a popular tide" ${ }^{37}$ at the time Goldman began to criticize it, which was another reason

32 Emma Goldman, What I Saw, IISH-EGP, No. 284.

33 Ibid.

34 Ibid.

35 Ibid.

36 Emma Goldman to Roger Baldwin, London, November 6, 1924, IISH-EGP, No. 52, 2.

37 Ibid. 
why she did not get much support. And that despite the fact that, realistically, everyone with some knowledge about Russia and Bolshevism would have to have realized that the revolution had been betrayed. From Goldman's perspective, therefore, "all those who refuse to face the facts of Russia are dealing with nothing else but attitudes. Their emotions have blinded them to such an extent that they are utterly unable to listen to any critical analysis by people who speak, not from hearsay, but from actual experience and knowledge." 38 It might have been Goldman's attitude of superiority with regard to knowledge about Soviet Russia that also repelled her British audiences a bit, but Goldman's evaluation of attitudes would of course only have included others' attitudes and not her own.

However, the steady confrontations with other left intellectuals about Bolshevism also made Goldman melancholy, as a letter to Berkman from 22 December 1924 shows: “As it is I am a wreck from lack of sleep and feel ill all over. It is mainly the realization of the terrible power of the Bolshevik lie which so depresses me." 39 The radical milieu in London, in addition, was quite different from the one in New York City, about which Goldman also complained: "If only we had people of our own. That is the bitter thing to me; we have absolutely no one, not among the English people, and the Jews are unknown. It is heart breaking. I must therefore have some committee and I will not get it for what I had intended to do [i.e.] present the facts about Russia and my conclusions. God damn that fake Purcell.”40 Albert Arthur Purcell (1872-1935) was a British trade unionist and probably Goldman's fiercest antagonist with regard to the interpretation of Bolshevism. He had also denied Goldman access to the trade unions, where she was consequently not allowed to lecture. In general, it was problematic for Goldman to find places to lecture about Soviet Russia. Kingsway Hall was not an option, as the organizers were afraid of communist interventions during one of Goldman's speeches, while it was also not easy to cover such events financially. ${ }^{41}$ Goldman asked Berkman for help with regard to statements from Russian Menshevikis and Social Revolutionaries, which she could probably use as witness accounts for her lectures, but in general the former "queen of anarchists" was alone and "sick talking, talking, talking about R[ussia] and yet not move any one of these politicians." 42 Goldman became really frustrated with her British comrades and told Berkman that "[t]o move Anglo Saxons from any of their

38 Ibid.

39 Emma Goldman to Alexander Berkman, London, December 22, 1924, IISH-ABP, No. 23, 2. 40 Ibid.

41 Ibid., 1.

42 Ibid., 2. 
preconceived ideas is like moving the Rockies." ${ }^{43}$ Communists would in addition interrupt her meetings, and it was almost impossible to find a place to lecture on a more regular basis. A representative of a professional lecture agency at the same time was "afraid of the disturbance made by the Communists that would give his bureau a bad reputation," 44 which was why Goldman could not hope for a more steady income from lecture tours either. With regard to her publications and income from single lectures here and there, her financial situation would hardly become any better: "Even if I should succeed in work on Russia I could not accept any money from lectures or meetings. I could not stand the thought of it. On the other hand I am not hopeful of getting stuff accepted here, not enough to secure me for very long." 45

In February 1925, Goldman, regardless of her financial shortcomings in London, established the British Committee for the Defense of Politicals in Russian Prisons, and although she was only able to attract a few members early on, the anarchist did not give up hope. ${ }^{46}$ Although Berkman suggested looking for some better options in order to publish regular articles, which would then also give Goldman a bit more financial security, ${ }^{47}$ nothing much changed, and by the end of February 1925, Goldman had only £41 left, "just about enough for two months, what then? I see no chance whatever of earning a penny by writing, and I can take no money from our people for lectures on Russia. I am terribly worried." ${ }^{48}$ The female anarchist also had trouble when she was looking for a cheaper place to stay, as "[t]he English beat the Germans in prudery and hypocrisy when it comes to women," 49 especially when Goldman was looking for a place to live alone. Yet even more troublesome was the British attitude towards Moscow, particularly from left intellectuals, because, as Goldman wrote to Berkman, other than themselves, "everybody else has been hypnotized. We know how well the Moscow gang can do it, don't we?"50

The British Trade Union Report about Russia by the delegation that had visited the Soviet Union in late $1924^{51}$ was another blow for Goldman, who could

43 Emma Goldman to Alexander Berkman, London, January 5, 1925, ABP-IISH, No. 23, 1.

44 Emma Goldman to Alexander Berkman, London, Febuary 2, 1925, ABP-IISH, No. 23, 3.

45 Ibid.

46 Emma Goldman to Alexander Berkman, London, Febuary 5, 1925, ABP-IISH, No. 23, 1.

47 Alexander Berkman to Emma Goldman, Berlin, February 6, 1925, ABP-IISH, No. 23, 2.

48 Emma Goldman to Alexander Berkman, London, Febuary 25, 1925, ABP-IISH, No. 23, 1.

49 Ibid.

50 Ibid., 2.

51 Trade Union Congress, Russia: The Official Report of the British Trade Union Delegation to Russia in November and December 1924 (London: Co-Operative Printing Society, 1925), Warwick 
simply not believe why such an uncritical view on Bolshevism could continue to be repeated. Goldman was really in a bad mood: "I shall not be able to swim against the terrific stream of prejudice any longer." ${ }^{52}$ To Berkman, she wrote plain and clear that "the situation here is too impossible, the conspiracy of silence too thick, the prejudice too much, I must have something that would help me in the struggle. I feel a pamphlet would be a tremendous weapon." ${ }^{25}$ She therefore hoped that her friend would write her such a pamphlet, which could then be used to hold up the fight against pro-Bolshevist lies. Goldman was quite disappointed when Berkman turned her down this time, as he was busy working on his own projects. ${ }^{54}$ While she was quite disappointed, it did not take her long to forgive her lifelong companion, whom Goldman really appreciated for being a part of her radical and emotional life: "The greatest of joys however is the fact that you have remained in my life, and that our friendship is as fresh and intense as it was many years ago, more mellow and understanding than when we were both young and unreasonable. My heart goes out to you on this our day with deep love and devotion." ${ }^{55}$ It might have been the security of always being able to rely on Berkman in her life that gave Goldman some spirit to continue her fight against Bolshevism in Britain as well, although "Moscow buys everybody, directly, or indirectly. It is like swimming against the flood."

At the same time, Goldman did not want to cooperate with other anti-Bolshevist forces and prohibited Mensheviki from becoming members of her British Committee for the Defense of Politicals in Russian Prisons because she feared a numerical takeover. In a way, she thereby sabotaged her own work, but in a letter to Berkman from 8 June 1925, Goldman simply claimed: "I do general propaganda against the regime in $\mathrm{R}[\mathrm{ussia}]$, and not merely work for the politicals. In the case of the latter one certainly must include all who are victimized by the Moscow outfit, all Socialist factions. ${ }{ }^{57}$ However, she also had to confess that anarchists in Britain offered no more reason than other political movements and were "as unreasonable, intolerant, and fanatical as the rest," 58 a fact that made Goldman's position even more tragic. That her and Berkman's books about Soviet

Digital Collections, No. 292/4/21/36. Accessed May 20, 2020, https://wdc.contentdm.oclc.org/ digital/collection/russian/id/11.

52 Emma Goldman to Alexander Berkman, London, March 16, 1925, ABP-IISH, No. 23, 1.

53 Ibid.

54 Emma Goldman to Alexander Berkman, London, March 19, 1925, ABP-IISH, No. 23.

55 Emma Goldman to Alexander Berkman, London, May 18, 1925, ABP-IISH, No. $23,1$.

56 Emma Goldman to Alexander Berkman, London, June 6, 1925, ABP-IISH, No. 23, 1.

57 Emma Goldman to Alexander Berkman, London, June 8, 1925, ABP-IISH, No. 23, 1.

58 Ibid. 
Russia, as was discussed in the previous chapter, did not sell too well was bad, but for Goldman this was not related to the works per se. Since the reviews of Berkman's book were "simply marvelous," she argued, the reason for the failure of their books on the market must have been bad advertising by the publisher. ${ }^{59}$ Regardless of some good reviews, however, Goldman did not seem able to find substantial support for her anti-Bolshevist activities in the United Kingdom.

Even Bertrand Russell, an intellectual she had had high hopes for when she met him in Moscow before, let her down while she was in London. He had invited her to visit him to talk about the Soviet Union in early October 1924, ${ }^{60}$ and they met again in November of the same year to continue their talk. ${ }^{61}$ In February 1925 Goldman, who had tried to recruit Russell for a lecture series, sent him a letter in which she expressed her disappointment about his reluctance to help to shed light on the failure of Bolshevism:

[A] series of lectures on various phases of the Russian Revolution [is going] to take place in different parts of this City, in Town Halls. I am telling you this, not because I think you have any interest but simply that you may know that there are a few people in this country who feel the need of light on Russia. I had hoped that you would be among the first to see that need. I confess I am painfully disappointed that you, who so bravely and brilliantly stand out for the truth, should find it necessary to keep aloof from any critical work of the regime which has crushed the truth. ${ }^{62}$

However, Goldman tried again to persuade Russell to support her cause: "I appeal to you, Mr. Russell, if you do not want to ally yourself with me, that is of course your right, but do not remain silent in the fact of such wrongs as are being perpetrated every day by the Tchecka and by those in power in the Russian Government." ${ }^{23}$ Russell replied a few days later, but the answer was far from causing cheer for Goldman:

I am prepared to ... protest to the Soviet Government, on documented statements as to the existing evils; ... But I am not prepared to advocate any alternative government in Russia: I am persuaded that the casualties would be at least as great under any other party. And I do not regard the abolition of all government as a thing which has any chance of being brought about in our lifetimes or during the twentieth century. I am therefore unwilling

59 Emma Goldman to Alexander Berkman, London, July 13, 1925, ABP-IISH, No. 23, 1.

60 Bertrand Russell to Emma Goldman, London, October 2, 1924, EGP-IISH, No. 144.

61 Bertrand Russell to Emma Goldman, London, November 30, 1924, EGP-IISH, No. 144.

62 Emma Goldman to Bertrand Russell, London, February 9, 1925, Emma Goldman Papers, New York Public Library, Manuscripts and Archives Division, ZL-386, Reel 1 (henceforth EGP-NYPL), 1. A copy of this letter can also be found in EGP-IISH, No. 144.

63 Ibid. 
to be associated with any movement which might seem to imply that a change of Government is desirable in Russia. ... I think ill are the Bolshevisk in many ways, but quite as ill as their opponents. I feel that your movement, even against your wishes, will appear as political opposition to the present Soviet Government. ${ }^{64}$

Regardless of his reluctance to support anti-Bolshevist activities, in a letter to Berkman from 15 June 1925, Russell confirmed that he had the same opinion about Bolshevism as the anarchist, whose work on the Bolshevist myth Russell had carefully read: "My judgement of the Bolsheviks is substantially the same as yours; I went through the same disenchantment, having come with the same hopes." 65

At the same time, for Goldman, Russell's unwillingness to join her efforts against the Bolshevist regime on behalf of political prisoners in the Soviet Union was another blow to the anarchist's activities in London. She must have felt alone, without friends and comrades to support her, and the fact that her and Berkman's books were not perceived very well by a larger audience also seemed to show her that her former level of notoriety and celebrity had diminished. It was no different with regard to the United States, as the American press now mostly relied on other voices; while Soviet Russia was a topic of interest, "[t]he early pro-Soviet American observers of the Russian Revolution were a picturesque and adventurous group of 'poetic journalists and journalistic poets,' as they were sometimes called at the time." ${ }^{\prime 6}$ Positive attitudes towards Lenin and Trotsky were consequently shared by many left intellectuals in the United States as well, and when Goldman began her anti-Bolshevist activities in early 1922, she was consequently criticized for damaging the image of the Russian Revolution. It was hard for Goldman to counter these opinions, especially as her influence there had vanished since she had been deported in late 1920. In addition, she had criticized famous figures in the United States like Bill Haywood for his involvement in the recruitment of American workers for the Kuzbass Autonomous Industrial Colony. ${ }^{67}$

When Goldman reflected about "Good and Evil Points in the Makeup of America," she had to acknowledge that the Russian Revolution had failed to

64 Bertrand Russell to Emma Goldman, London, February 14, 1925, EGP-IISH, No. 144, 2-3. 65 Bertrand Russell to Alexander Berkman, London, June 15, 1925, EGP-IISH, No. 144.

66 Dimitri von Mohrenschildt, "The Early American Observers of the Russian Revolution, 19171921,” The Russian Review 3, no. 1 (1943): 65.

67 Letter to Roger Baldwin, London, January 5, 1925, EGP-NYPL, 4. Berkman also criticized Haywood: "Of course, it is easy for an American labor leader, playing to the radical element, to write glowing reports about the condition of the Russian workingmen, while he is being entertained at State expense at the Lux, the most lucrative hotel in Russia.” Berkman, The Russian Tragedy, 6. 
start a world revolution that could have freed the world and that, at the same time, "the exploitation of the masses is nowh[e]re quite so intensive as in the United States." ${ }^{68}$ It was quite sad that events in Soviet Russia since 1917 had failed to provide a revolutionary stimulus in North America and that, at the same time, so many left intellectuals believed the news from Soviet Russia that was still painting a utopia rather than the reality of Bolshevist state rule. She would also receive quite a lot of criticism for her attitude towards the American Left, including former anarchist comrades of hers, which, especially when they were received from friends of the past, must have been painful for her as well. Some letters from Ben Reitman must have been particularly heartbreaking for Goldman.

In late January 1925, Reitman had written a letter to his former lover, explaining to Goldman that he had left his radical times behind and now would spend his life as a physician and that he had turned to religion, of all things: "Jesus and some religious activity are apparently the next big factor in my life. Jesus is always wonderful to me. He's like a lover who once beautifully seduced your mind and body, and 'satisfies your longing as nothing else can do." ${ }^{69} \mathrm{He}$ also told Goldman about his wife Anna, who "is a worthy successor. As the years pass on we have learned to make the adjustment that makes [our] relationship fairly beautiful and home desirable."70 Reitman nevertheless emphasized that he had a high opinion of his anarchist lover of the past:

Many of your lectures and interviews in Berlin or Paris or London are gossip at the American breakfast table. You were a great woman, you are a great woman, and when you cross the bridge to the Great Unknown, you'll still be great. Posterity will give you a proper appraisal. Your great brain, your mighty voice, your tremendous love for the poor and the downtrodden, your hatred for injustice and stupidity, your divinity, will never die. ... In the last half a dozen years I've written to you seldom. There was really nothing much to say. But I say to you now what I have said to my friends, and in public-that Emma, you're a very great woman. You're a child of the gods. The decade associated with you and your work was the greatest period in my life. ${ }^{71}$

A close reading of Goldman's and Berkman's works about Soviet Russia, however, seemed to have changed this opinion, as another letter from Reitman in July 1925 provided a totally different evaluation of the anarchist and her personality,

68 Emma Goldman, Good and Evil Points in the Makeup of America, n.d. [1924], EGP-IISH, No. $189,3$.

69 Ben Reitman to Emma Goldman, Chicago, IL, January 28, 1925, EGP-IISH, No. 132, 1. 70 Ibid. 2.

71 Ibid. 
which should be presented here as well. Reitman must have truly hurt Goldman with his letter from 10 July 1925, and consequently it is quoted here at some length:

Your first book on Russia left me sympathetic to Russia. I felt that Russia gave you a chance in the world, that they put themselves out to let you and Sasha work and be helpful but true to yourselves. YOU WERE AS YOU ALWAYS WERE HARD^ ${ }^{\star}$ CRITICAL* BITTER` SELFDETER-

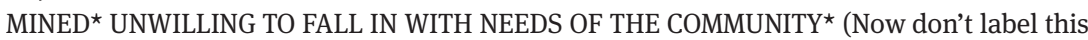
refusal to compromise). What I am trying to say [is] that you and Sasha wanted your way (and that is characteristic of the ANTI-Mind) and refused to work for God, for society, or humanity or what ever you may call it unless it was your way. ... You are always knocking, kicking, criticizing, seeing the worst side of everything, whining until you have your reader HATING $^{\star}$... you have no idea of your whinfulness and bitterness and unjust critical attitude. Wake up and be happy. ... when I understood that the Bolshevist has to deal with minds like your[s] I was not surprised at the Kronstadt bombardment and Prisons and all the terribel [sic!] things they did to the ANTIMINDS-yes you are a typical antimind you always oppose the thing that is ... How in the hell could the Bolshevists live and thrive if they allowed you and minds like you[rs] to have power ${ }^{\star}$... Your and Sa[s]ha['s] books convince any thoughtful student that MINDS like your[s] will never permit the world to have anything that approaches Socialism or much less Anarchism. I think the Bolsheviki were kind to you and you were most unjust to them. ${ }^{72}$

In her reply, Goldman somehow underplayed her anger and just wrote: "If anything at all, your letter amused me. You must have thought that you are preparing a sermon for your congregation, a regular Billy Sunday sermon, fire and brimstone upon the heads of us poor sinners." ${ }^{\prime 73}$ She also disagreed with Reitman's accusation that she and Berkman had prevented her former manager from using his literary talent. She now even encouraged him to use his accusations against the two anarchists in his planned book: "If you are going to say the same things about me in your book as you have in your last letter, your book will be a great seller, the Communists will buy up the entire edition." between the two former lovers, however, clearly highlights one problem Goldman was facing with regard to the US audience and her works about Soviet Russia. Many would share Reitman's evaluation, and the fact that Goldman had waited until 1922 to share her criticism, when the discourse about Bolshevism had been heavily shaped by other works and opinions, made it hard for her to gain both credibility and interest in her work alike.

72 Ben Reitman to Emma Goldman, Chicago, IL, July 10, 1925, EGP-IISH, No. 132, 1-2. Emphasis in the original.

73 Emma Goldman to Ben Reitman, London, August 4, 1925, EGP-IISH, No. 132.

74 Ibid. 
Goldman also had some important correspondence about Bolshevism with Roger Nash Baldwin (1884-1981), the first executive director of the American Civil Liberties Union, whom she considered to be one of her pupils and friends. ${ }^{75}$ Baldwin supported Goldman in her struggle to support political prisoners in the Soviet Union and shared her worries about the Bolshevist lies that were still having a strong influence in the Left's milieu. From Berlin, she wrote to Baldwin on 3 June 1924 as follows: "I am so glad that you have taken up the cause of the unfortunate victims of Soviet rule. Believe me it was highest time. So many lives could have been saved, so many truly worthwhile people rescued from despair and suicide if most of the radicals had not been so completely under the hypnotic influence of Moscow."76 However, Goldman was not surprised by the latter fact, as she knew "the hypnotism was unavoidable, I was under its spell for many months myself. I can, therefore, understand everybody who is still in the trance."77 Regardless of her understanding, she tried to unmask the "myth, which will have it that Bolshevism, Leninism and the Russian Revolution are identical. It is this myth which prevents people from seeing that Bolshevism has crushed the Revolution and is now crushing the best there is in Russia."78 Goldman thought she had no choice, because as long as this myth remained in place, the Bolsheviki could continue their rule of terror and many innocent people would be sent to jail simply for having different opinions about the revolution and the form of government it had eventually resulted in. The world had to see that the revolution had been betrayed, its ideals corrupted and its supporters imprisoned, and Goldman attempted to do everything necessary and use her knowledge and experience to provide the true narrative about the political developments in Soviet Russia since 1917, no matter if the left in particular tended to ignore the valuable first-hand insights she had to offer. In this regard, she explained to Baldwin that

75 Goldman wrote as follows to Arthur Ross on 30 December 1933: “I can assure you that I never at any moment doubted the sincerity of Roger Baldwin, or his friendship for me. Don't forget he is a pupil of mine. And while not all pupils give cause for pride on the part of their tutors Rogers [sic!] stand during the war had already been sufficient to gladden my heart. The work he has been doing in the States since our deportation made him stand out among all those who had claimed me as their teacher. No, I had never doubted his sincerity. But I had too many occasions to doubt his judgement in a number of issues. Primarily, I found him most naive in his faith in people in authority. Being perfectly honest himself he takes everything as gospel truth what his friends in power tell him." Emma Goldman to Arthur Ross, Toronto, December 30, 1933, EGPTAM, Box 1, Emma Goldman Correspondence to Arthur Ross, Jan. 4, 1933 - Dec. 30, 1933, 1. 76 Emma Goldman to to Roger Baldwin, Berlin, June 3, 1924, EGP-NYPL, 1.

77 Ibid.

78 Ibid. 
The Soviet Government with its experiment and method has had a most deteriorating and disintegrating effect both on revolutionary thinking and organization. In fact, it has poisoned the whole social and revolutionary movement. It has inculcated distrust, espionage and cynicism in the ranks of the masses unknown since the days of Jesuitism; it has discredited everything of any value ever fought for by revolutionary men and women the world over. To my mind, it has perverted revolutionary thinking and organization. ${ }^{79}$

This perversion needed to be understood by those who still supported Bolshevism and who still believed that Lenin had actually worked for the development and not the corruption of the revolutionary process. With regard to the anti-oppositional policies of the Bolsheviki, Baldwin declared in a response to Goldman on 24 November 1924:

1) That the persecution of opponents is not only wholly unnecessary but destructive of revolutionary progress, not only because it kills off those whose contributions are most needed, but because it imposes the temper of tyranny on the ruling classes;

2) That the centralization of power in the hands of a bureaucratic government is having the same effect of killing off those spontaneous experimental growths toward communal production and distribution which alone seem to me an enduring basis of economic stability in which the individual can find his widest freedom. ${ }^{80}$

He consequently agreed with Goldman, and this must have been a moment of joy for her in those days, although Baldwin would argue, like many others, that the Bolsheviki had no other choice than to use violence to defend themselves against the enemies of the revolution. Goldman disagreed on that point, as she considered the Bolshevist state and its government to be "the very institution which made political terror inevitable." ${ }^{11}$

Goldman also highlighted more than once that "while I am opposed to Bolshevism and fight it with all my abilities, I am yet in deep sympathy with the Russian Revolution and the Russian people; it is because I feel that there is an abyss between the Revolution and Bolshevism that I have taken my stand against the latter." ${ }^{82}$ In response to Baldwin's argument that the Bolshevist terror was a necessary evil that had to be accepted for the eventual success of the revolutionary process, Goldman angrily declared:

I insist that the terror used by the Bolshevik Government has not been imposed upon them by outside circumstances but is inherent in the Dictatorship. It is that which compelled

79 Excerpts from a letter from Emma Goldman to Roger Baldwin, November 1924, EGP-NYPL, 2.

80 Roger Baldwin to Emma Goldman, New York, November 24, 1924, EGP-NYPL, 2.

81 Emma Goldman to to Roger Baldwin, London, January 5, 1925, EGP-NYPL, 2.

82 Emma Goldman to Mrs. J.D. Campbell, St. Johns Wood, London, January 30, 1925, EGP-NYPL. 


\begin{abstract}
Lenin and the rest to eliminate every one who could or would not bow to the Dictatorship, I do not deny that counter-revolution from within and intervention from without may not in a measure have been a contributory factor. But they also helped to strengthen the arm of the Dictatorship because they furnished it with ever so many excuses for the terror employed. But over and above that is the idea of the Dictatorship, the obsession that the transformation period must be directed by an iron hand which at the exclusion of all other methods will impose itself upon the whole country. ... There is no difference ... between the old belief of Divine rights of the King whom God hath put on the throne, and the Divine rights of the Bolsheviki whom Marx hath put on the throne and the Tcheka continued to keep there. ${ }^{83}$
\end{abstract}

Those who actually still believed in the continuation of the Russian Revolution and the idea that the Bolsheviki had really established a dictatorship in the name of workers and peasants must, in Goldman's view, have been naive, and she called Baldwin "really childish" for his hopes: "The fact is that today the dictatorship is like all governments in the interest of a privileged class and that class is the Communist Party with those who are working with the Communist Party for material reasons and not out of conviction, and the ultimate aim of that privileged class is State Capitalism with all the resultant evils that Capitalism contains."84

In later years, Goldman would continue to use her lecture tours, such as in Canada, to collect money for political prisoners in the Soviet Union ${ }^{85}$ or to highlight her position against Bolshevism, usually pointing out that they had nothing in common with the Great Revolution that was supposed to have led the way to a better future in the 20th century. However, her attempts were not always successful; for example, she described her experience in Montreal during her Canadian lecture tour in 1926/27 as follows: "[M]y visit there was not crowned with great success. In fact I was so discouraged I wanted to take the next steamer back ... But I am not made to give up easily. I stuck out Montreal though the meetings were badly organized, hence badly attended, only two English meetings tried and given up because of lack of interest, and mainly I felt rotten because I found no spirit whatever among the Montreal comrades of whom there are very few." ${ }^{86}$ While "Montreal was disheartening," 87 her experience in Toronto, where Yiddish lectures also attracted larger audiences, provided a more hospitable environment and was much better, and this cheered up Goldman a bit. The

83 Emma Goldman to Roger Baldwin, Norwich, April 20, 1925, EGP-NYPL, 1-2.

84 Ibid., 2.

85 Emma Goldman to Doris Zhook, Toronto, December 24, 1926, EGP-TAM, Box 1, Emma Goldman Correspondence to Doris Zhook et al., Dec. 24, 1926-Jul. 31, 1939, 1.

86 Ibid.

87 Ibid. 
main success of her lecture tour in Canada, however, was her proximity to the United States and having the chance to meet family members, like her niece Stella, and some friends in person. Regardless of her initial heaviness of spirit and the relatively small success in attracting larger audiences to her lectures, in the end, the Canadian tour allowed her to raise more than $\$ 300$ that would be sent to Berkman to support anarchist prisoners in the Soviet Union. ${ }^{88}$ Regardless of her experience, Canada seemed to have become a possible alternative for a place to stay in the future, according to Goldman's summary of the tour that was sent to her friend Doris Zhook:

As I already said, I do not think I will get much out of this visit, but as I am coming back in March for another month, I hope then to raise part of my expenses of coming here. And of course I am also going back to Montreal before sailing. I do not think I will get away from Canada before May, in fact the comrades are very anxious for me to remain here altogether, or at least for a year or two. I am certain if I would put in as much effort as I did in England the results would be far beyond anything I had there. However, it will be impossible for me to remain here for next winter, but at least I know there is a field in C[anada] I can turn to. That is something. ${ }^{89}$

Yet it would be St. Tropez, where Goldman bought a house for Berkman and herself in 1929, where she eventually settled. The first installment of 30,000 Francs was, as mentioned before, paid by some of her friends, and a sum of 50,000 Francs remained to be paid in the following years. Goldman hoped to cover these costs with proceeds from her autobiography that she was then working on. ${ }^{90}$ Her 50th birthday, according to the famous anarchist, "was certainly the most perfect birthday I have had since I became a conscious human being," and Goldman enjoyed it a lot: "After our tea, we had a grand banquet. ... We had ordered our dinner, and believe me, it was the grandest feed I have had in years-perfectly prepared and exquisitely served. Then we danced and danced and danced." ${ }^{91}$ The next morning, however, was terrible as Goldman was quite sick. But nonetheless, she was positive with regard to her future that day: "[I]t seems nothing will kill E[mma] G[oldman] except death, and if she can help it

88 Emma Goldman to Doris Zhook, Winnipeg, January 17, 1927, EGP-TAM, Box 1, Emma Goldman Correspondence to Doris Zhook et al., Dec. 24, 1926-Jul. 31, 1939.

89 Ibid.

90 Emma Goldman to Doris Zhook, St. Tropez, July 3, 1929, EGP-TAM, Box 1, Emma Goldman Correspondence to Doris Zhook et al., Dec. 24, 1926-Jul. 31, 1939, 2. She commented on her purchase as follows: "It is a comfort to know that in my old age I will have a roof over my head and a definitive place to which I can return and where I can keep my books which are the only valuable things I have." Ibid.

91 Ibid., 3. 
she is going to tell the Old Gentleman to wait at least until her book is completed." 92

The book in question here was her autobiography, which would fulfill two purposes. On the one hand, it gave Goldman a chance to reflect upon her five decades of life, and on the other hand, it genuinely seemed important to her and she really hoped that it would help her to gain some income to take her financial sorrows away from her consciousness. Her attorney Arthur Ross would help her with that, and on 18 July 1929 she informed him that she was aware of the problems with selling such an extensive work: "I quite agree with you that two volumes of a work, unless it is a novel, are a dangerous undertaking. I am going to insist with the publisher who will bring out my book to make it one large volume."93 Yet Goldman wanted 15\% royalties, which was a demand that did not comply with the sales of her last works. Knopf, the publisher, offered her a \$4,000 advance payment and $10 \%$ on the first 5,000 copies. Afterwards, Goldman would get the demanded $15 \%$, but the anarchist also considered Simon \& Schuster for an obvious reason: "I realise that Knopf from a point of quality as a publisher is perhaps preferable than Simon \& Schuster, but on the other hand, the latter are the most skillful advertisers and recklessly enterprising. More than any other publisher ... Schuster ... would get my book over in a large way. That is my reason for begging off from Knopf until I hear from the others." 94 Goldman had clearly understood two things: 1) how capitalism worked, and 2) the fact that she probably only had this one shot left to make sure that she would not face financial troubles in the years to come. The Canadian lecture tour had already shown her that her star had been fading in the years since 1917, and now she needed to make the best out of her situation; therefore, she was trying to get the best possible deal with the best paying publisher.

Liveright, with whom her last works had been published, was out of the question for her this time. They had failed to publish and advertise her books on her Soviet Russian experience appropriately and therefore could not offer what she expected for her autobiography. In addition, Horace Liveright had previously sent her an unfriendly letter: "A man who can write in the tone that Horace L. did is not an agreeable person to deal with. I therefore want to get out of having anything to do with him unless there should be some hitch with Knopf."95 Ross was supposed to negotiate with Knopf and demand the fulfillment of three

92 Ibid.

93 Emma Goldman to Arthur Ross, St. Tropez, July 18, 1929, EGP-TAM, Box 1, Emma Goldman Correspondence to Arthur Ross, Jul. 18, 1925-Dec. 23, 1929, 1.

94 Ibid., 2.

95 Ibid. 
essential points: 1) the book should be published in one volume, 2) it should cost less than \$5, and 3) Knopf should actually advertise the book. ${ }^{96}$ At the same time, Goldman wanted to keep the European rights for her book-she had already had offers from a German and a Danish publisher-regardless of the language, which also meant retaining exclusive rights to sell her book in Britain, while Knopf would only hold the rights for the United States and Canada. ${ }^{97}$ The autobiography's sale price was important, as Goldman wanted to reach the widest possible audience, albeit no longer for her anti-Bolshevist views but for a reflection on her life and impact:

You are quite right that I cannot insist on whether my book is to appear in one or two volumes, and the same applies to the selling price of the book. My only reason for mentioning these points is that a one volume autobiography is likely to sell better, and a $\$ 5.00$ edition, though prohibitive for a great many people, would nevertheless not be so exclusive as $\$ 7.50$. After all, we need not deceive ourselves. The people most interested in the story of my life will be intelligent advanced workers and professional people and they are the very ones who cannot afford such a high price. ${ }^{98}$

Goldman was very picky on these details, because, as mentioned before, the formerly famous anarchist had realized that her career had already declined and that her last deal needed to be a big one to make a nice life in St. Tropez affordable for the years that remained for her and Berkman. To Ross she confessed that

I hate awfully to seem to you or Knopf "captious.” Any one who knows me well knows that it is not my nature and that I have not practised such things. But I cannot emphasize too strongly in my letters to my dear ones, of whom you are one, that my book is my first and last chance in life to get enough material results to secure myself for whatever few years there are left me to live. It is for this reason that I am very eager to make the best possible arrangements with Knopf in regard to the returns that are likely to accrue from the publication of my autobiography.

While she had agreed to limit herself with regard to the extent of her autobiography to secure higher sales, the 300,000 - 350,000 words seemed too few for her into which to pack her whole life. ${ }^{99}$ At the same time, Goldman was willing to

96 Emma Goldman to Arthur Ross, St. Tropez, August 8, 1929, EGP-TAM, Box 1, Emma Goldman Correspondence to Arthur Ross, Jul. 18, 1925-Dec. 23, 1929.

97 Emma Goldman to Arthur Ross, St. Tropez, August 24, 1929, EGP-TAM, Box 1, Emma Goldman Correspondence to Arthur Ross, Jul. 18, 1925-Dec. 23, 1929, 1-2.

98 Ibid., 2.

99 Emma Goldman to Arthur Ross, St. Tropez, September 10, 1929, EGP-TAM, Box 1, Emma Goldman Correspondence to Arthur Ross, Jul. 18, 1925-Dec. 23, 1929, 3. 
leave the translation rights to Knopf, who had obviously treated her better than Liveright: "I am writing him today ... simply to tell him I am satisfied with his assurance of a large advertising campaign, as well as with the general tone he has maintained so far. In fact I must say I am delighted to find in Knopf a man of such fine tact and large spirit."100

As long as these legal issues remained unsettled, Goldman seemed hardly able to focus on actually writing. ${ }^{101}$ Knopf eventually offered her a \$7,000 advance if world book rights were secured for the publisher, and Goldman agreed with Ross that it would actually be easier to let the publisher handle such issues once the book was finished and ready for sale, ${ }^{102}$ a process that had been slowed down by Goldman, who had had some other writing obligations on the one hand and the possibility to live rent-free in Paris for a while on the other. ${ }^{103}$ Once the

100 Ibid., 4. Goldman emphasized that the Jewish community in the United States would probably be the one that was most interested when it came to possible translations for Knopf. While Knopf would get the translation rights, he was supposed to secure Goldman's interests as well. Goldman wrote to Ross about this on 15 September 1929: “[I]n whatever country he [Knopf] gives permission for the publication of my book he should ask for advance on royalties. I know that the $\$ 2,000 \mathrm{I}$ am to get soon and the $\$ 2,000$ when the manuscript is completed look like a very large amount of money. It is, of course. But I have many debts and I am dying to get a rest away somewheres [sic!] from writing. Inasmuch as there will be no returns from royalties on the book until the $\$ 4,000$ are deducted, I will need more money to keep me in comparative comfort and peace of mind. For this reason I am very anxious to get advance sums wherever I possibly can.” Emma Goldman to Arthur Ross, St. Tropez, September 15, 1929, EGP-TAM, Box 1, Emma Goldman Correspondence to Arthur Ross, Jul. 18, 1925-Dec. 23, 1929, 1.

101 On 19 September 1929, she wrote to Ross that "I will be happy when the business end is settled and I can again give myself wholly to writing. I am very unfortunate in being so easily distracted from my work. Every little thing ruins my mood. Perhaps I am only grabbing at such distractions as an excuse, like children who do not like school. However, once the material end is off my back and my visitors have left me at the end of the month I will again be able to write like a house on fire.” Emma Goldman to Arthur Ross, St. Tropez, September 19, 1929, EGPTAM, Box 1, Emma Goldman Correspondence to Arthur Ross, Jul. 18, 1925-Dec. $23,1929$.

102 Emma Goldman to Arthur Ross, St. Tropez, September 24, 1929, EGP-TAM, Box 1, Emma Goldman Correspondence to Arthur Ross, Jul. 18, 1925-Dec. 23, 1929, 1.

103 Emma Goldman to Arthur Ross, St. Tropez, September 29, 1929, EGP-TAM, Box 1, Emma Goldman Correspondence to Arthur Ross, Jul. 18, 1925-Dec. 23, 1929. Accorrding to her letter, the Ladies' Home Journal had offered her \$2,000 for an article and it still seemed like that her ties to the female bourgeois elites in the United States were still financially worthier than those to the US workers' movement. The journal later rejected Goldman's article and the literary agent Mr. Bye accused her of having sent a bad article so as to easily keep the $\$ 700$ advance payment. See Emma Goldman to Arthur Ross, Paris, November 8, 1929, EGP-TAM, Box 1, Emma Goldman Correspondence to Arthur Ross, Jul. 18, 1925-Dec. 23, 1929, 1 and Emma Goldman to Arthur Ross, Paris, November 13, 1929, EGP-TAM, Box 1, Emma Goldman Correspondence to Arthur Ross, Jul. 18, 1925-Dec. 23, 1929, 1. Goldman consequently did not believe "that anything 
contract with Knopf had been signed, however, Goldman felt the pressure on her mind to finish the book: "Human nature, though, is a contrary thing: now that everything is settled, I may find it more difficult to keep going, and heavens only knows it has never been anything else but difficult since I began writing the story of my mad life. The thought that I am pledged to a difinite [sic!] date has already started to haunt me."104

Nevertheless, when Goldman received the first payment installment from Knopf over \$3,325, she felt "certain that everything is contained that ought to be in that legal document" and thanked Arthur Ross for his steady support. ${ }^{105}$ What she was unhappy about was the fact that she needed to pay taxes on her royalties from Knopf in the United States: "I think it is a rotten shame that I should have to sustain the U.S. Government. Instead of giving me an indemnity for depriving me of citizenship, raiding our office and robbing us of everything we had built up in the way of literature etc., I am now compelled to pay a tax on the royalties of my book. This serves to prove my contention that governments are cut-throats, even worse than ordinary hold up men." ${ }^{106}$ At the same time, she felt "entirely indebted to some American publishers I have dealt with for the lessons they gave me about the necessity of becoming 'a hard-boiled business woman."”107 This time, after her bad experience with Liveright in the past, she avoided a title being chosen by the publisher, who favored "Red Years" as a possible title. Goldman, who herself claimed to now be "on the way of becoming a 'bloated capitalist," "108 was nevertheless happy to have received quite a lot of money from the United States, which she bitterly needed at that time.

Goldman took $\$ 1,000$ immediately to pay off some debts, because for the previous eight months she had been borrowing from several friends to survive. The next payment of $\$ 650$ for the house was also due, and $\$ 500$ needed to be paid back to Ross, who had lent her some money for the initial down payment. The financial situation was tight, and she realized that "unless I get any returns from serial sales or articles, I will have to hang on to the second advance for a

has changed in America to make the average magazine less cowardly than they have been in the past.” Ibid., 2.

104 Emma Goldman to Arthur Ross, St. Tropez, October 6, 1929, EGP-TAM, Box 1, Emma Goldman Correspondence to Arthur Ross, Jul. 18, 1925-Dec. 23, 1929, 1.

105 Emma Goldman to Arthur Ross, St. Tropez, October 13, 1929, EGP-TAM, Box 1, Emma Goldman Correspondence to Arthur Ross, Jul. 18, 1925-Dec. 23, 1929, 1.

106 Ibid., 2.

107 Ibid.

108 Ibid., 3. 
long time because it is not likely ... [to] get another sou from royalties until Knopf has taken out his advance." ${ }^{109}$ To sell articles would also be hard, as long as Goldman insisted on her critical tone. ${ }^{110}$ At least Goldman was able to send her autobiography to Knopf, once Berkman had revised her manuscript. ${ }^{111}$ Her editor at Knopf, Harry Payne Burton, surprised her as, in contrast to her previous experience with US editors, he had done quite a remarkable job with Goldman's manuscript, and she wrote to him on 26 July 1930:

I cannot tell you how pleased I am to discover that you not only have good judgment, but that you have approached LIVING MY LIFE with sincerity, understanding and sympathy so seldom found in the average literary editor. ... Of course, most of the deletions you have made I had intended to make myself in the final revision. ... I hope some day I may be able to thank you in person, but that will only be possible if you come to Europe. With America more reactionary than when I had left it, there is no hope for Mohamed to come to the mountains. ${ }^{112}$

While many people had supported her during the process of writing and considered her work an important one, given its reflections upon the history of anarchism in the United States, she would be criticized again for her remarks on Bolshevism and Soviet Russia. American writer Upton Sinclair (1878-1968) had pointed out some spelling errors in Goldman's book, which Goldman commented on with the following remark: "I have a rotten memory for names anyhow and I can't boast of being faultless in my spelling. But I would take Berkman's word as final because he is perfect and almost as pedantic as you seem to be. Whatever corrections there will be will go to Knopf together with some other wrong spelling." 113 The female anarchist did not like this kind of nitpicking, but she angrily replied to another of Sinclair's criticisms, namely that she had not mentioned the Five Year Plan in her book: "Living My Life is a record of my experiences and not of mere hearsay or myths. And as I have not been in Russia since the new 'miracle' was begun I could not in good taste or veracity write about it. I thought you

109 Emma Goldman to Arthur Ross, Paris, November 4, 1929, EGP-TAM, Box 1, Emma Goldman Correspondence to Arthur Ross, Jul. 18, 1925-Dec. 23, 1929, 2.

110 Emma Goldman to Arthur Ross, Paris, November 28, 1929, EGP-TAM, Box 1, Emma Goldman Correspondence to Arthur Ross, Jul. 18, 1925-Dec. 23, 1929, 2.

111 Emma Goldman to Arthur Ross, Paris, December 23, 1929, EGP-TAM, Box 1, Emma Goldman Correspondence to Arthur Ross, Jul. 18, 1925-Dec. 23, 1929.

112 Emma Goldman to Harry Payne Burton, St. Tropez, July 26, 1930, EGP-TAM, Box 1, Emma Goldman Correspondence to Arthur Ross et al., Jan. 22, 1930-June 12, 1939.

113 Emma Goldman to Upton Sinclair, Paris, December 14, 1931, EGP-TAM, Box 1, Emma Goldman Correspondence to Arthur Ross et al., Jan. 22, 1930-Jun. 12, 1939, 2. 
as a writer would understand that. But it seems your desire to see in every Soviet move the hand of god has somewhat affected your literary values. That is as it must be with people who remain true to the church whatever its faults." ${ }^{114}$ It seems clear that Goldman still could not stand any pro-Soviet opinion or demand.

In contrast to her position towards Sinclair, she thanked Baldwin for doing everything possible to promote the autobiography, which, as predicted by the anarchist, hardly found any customers in the United States, especially since the country had been struck by a recession since 1929. ${ }^{115}$ In April 1932, Goldman went on a book tour through Scandinavia, namely Sweden and Norway, to increase book sales there and to stimulate interest in translating her autobiography. At the same time, Goldman also dealt with Simon \& Schuster again, offering them some translations of European works, including a book by Sergei Tretyakov (1892-1937) published by Malik Verlag in Berlin. ${ }^{116}$ Berkman could, in the case of a contract, probably make some money from the translations, but Simon \& Schuster considered the offer too expensive. ${ }^{117}$ Goldman was again under financial pressure, and Ross helped her to prepare a lecture tour in the United States for $1934,{ }^{118}$ which would turn out to be her last visit to the country in which she had been active for so long. In 1933, meanwhile, Goldman lectured in less lucrative regions of the world, such as Wales ${ }^{119}$ and other parts of Britain, but the expected steady financial income from her autobiography failed to materialize.

For the once-famous anarchist, it was the publisher's fault that her autobiography's sales remained below the expected numbers: "Living My Life was botched in America owing to the mad price."120 Goldman still had hopes for the English market, but the book needed to be really cheap there, and her lectures

114 Ibid.

115 Emma Goldman to Roger Baldwin, Berlin, March 28, 1932, EGP-TAM, Box 1, Emma Goldman Correspondence to Arthur Ross et al., Jan. 22, 1930-Jun. 12, 1939, 1.

116 Emma Goldman to Clifton Fadiman, Simon \& Schuster, Inc. New York, St. Tropez, May 25, 1932, EGP-TAM, Box 1, Emma Goldman Correspondence to Arthur Ross et al., Jan. 22, 1930Jun. 12, 1939.

117 Emma Goldman to Clifton Fadiman, Simon \& Schuster, Inc. New York, St. Tropez, September 6, 1932, EGP-TAM, Box 1, Emma Goldman Correspondence to Arthur Ross et al., Jan. 22, 1930Jun. 12, 1939.

118 Emma Goldman to Arthur Ross, Toronto, January 4, 1933, EGP-TAM, Box 1, Emma Goldman Correspondence to Arthur Ross, Jan. 4, 1933-Dec. 30, 1933.

119 Emma Goldman to Doris Zhook, Glanamman, February 17, 1933, EGP-TAM, Box 1, Emma Goldman Correspondence to Doris Zhook et al., Dec. 24, 1926-Jul. 31, 1939.

120 Emma Goldman to Arthur Ross, London, March 12, 1933, EGP-TAM, Box 1, Emma Goldman Correspondence to Arthur Ross, Jan. 4, 1933-Dec. 30, 1933, 1. 
tended not to attract large audiences there either. ${ }^{121}$ Her British lecture tour had been rather eyeopening in this regard: "[M]y so called tour is over. I have to confess to having been defeated by the British. Their frigidity has a paralyzing effect on me. Their complacency drives me to drink. No, nothing can possibly happen to them that did to others. As to Fascism, of course, it will never come to England. All this in the face of the world cataclysm. ... I tried my damndest to make them realize that plague ... But it was all in vain."122 Just as Goldman had failed to persuade the British audiences that Bolshevism was something evil in the 1920s, she had also obviously failed with regard to fascism in the 1930s. It is hard to understand why Goldman at the same time believed that her book would sell well in Britain, but maybe her wishes had been the father of that thought, and Duckworth, ${ }^{123}$ a British publisher who had been in contact with Knopf, had already declined to buy more copies of Living My Life because they claimed that "there was no demand for it." 124 Goldman eventually wrote a letter to Alfred A. Knopf (1892-1994) himself, complaining about the situation:

\footnotetext{
It sounds as if you are holding me responsible for your losses on my book. Yet it was I who pleaded with you to make LIVING MY LIFE accessible to a larger public. In trying so hard to induce you to reduce your price, I was moved more by my concern in your returns than in mine. Surely that should have been proof enough that I did not want you to suffer any financial loss. I feel therefore that you are most unjust in throwing the blame for the unfortunate failure on my shoulders. After all, I did not sit on your doorstep and plead for your acceptance of LIVING MY LIFE. ... You know yourself that your loss is not due to [any] lack of quality of my work; that it was the crisis and your insistence on a prohibitive price. Why not admit that you had erred in the matter? None of us is always right, dear Mr. Knopf. No, not even you. ${ }^{125}$
}

She argued that Knopf's price was simply too high for a British audience and blamed the company for not granting review copies in larger numbers to promote her autobiography. ${ }^{126} 1933$ was consequently a bad year for Goldman, and that not only because she had to witness Hitler's final step to uncontested power in Germany.

121 Ibid., 2.

122 Emma Goldman to Arthur Ross, Jersey, May 1, 1933, EGP-TAM, Box 1, Emma Goldman Correspondence to Arthur Ross, Jan. 4, 1933-Dec. 30, 1933, 1.

123 Gerald Duckworth and Company.

124 Emma Goldman to Arthur Ross, Jersey, May 1, 1933, 3.

125 Emma Goldman to Alfred A. Knopf, St. Tropez, August 5, 1933, EGP-TAM, Box 1, Emma Goldman Correspondence to Arthur Ross et al., Jan. 22, 1930-Jun. 12, 1939, 1.

126 Ibid. 
While her positive perception of Knopf turned into anger the moment her autobiography had financially flopped, ${ }^{127}$ her Canadian tour for the next winter had also been canceled, since the money she had requested to secure her income and coverage of the costs could not be raised. While this situation was quite problematic for her, as she needed to create some financial income to cover the continuing costs, she remained enthusiastic and declared in a letter to Ross on 15 August 1933:

I seem to be like a cat. I [land] on my paws no matter how deep the plunge. I already wrote to England, Holland and a few other countries about a possible tour this winter. It is not only that I can't remain alone here in the bad weather. It is that I can not keep silent and inactive in the face of the harrowing event in Germany. I dislike England, I can't bear its frigidity and its complacency. I never yet had any kind of responce [sic!] in that damned country. But it will be preferable to sitting hands folded. As to the other countries. There are so few left where one may hope to be heard. ${ }^{128}$

Goldman was eventually granted the possibility to visit the United States for a lecture tour in 1934 and now included fascism as a topic into her lectures, although she used it in comparison with Bolshevism early on when talking about "the two dictatorships now infesting the world."129 Anticipating theories about totalitarianism by Hannah Arendt (1906-1975), Carl Joachim Friedrich (1901-1984) and Zbigniew K. Brzezinski (1928-2017) in later years, ${ }^{130}$ Goldman emphasized the similarities between the two ideologies and the methods left and right dictatorships shared:

127 Goldman wrote to Arthur Ross about the issue: "I finally had to give the man [Knopf] a piece of my mind. The stubborn mule has only himself to blame that he is still out so much on Living My Life. He keeps hinting that I am at fault after I had tired so desperately to make him see how absurd and downright criminal it had been to put the work out at $\$ 7.50$. Now, I [do not] give [a] damn whether he will have a cheap edition or not. I [have] had enough heart ache over the matter. I really can’t worry any more.” Emma Goldman to Arthur Ross, St. Tropez, August 15, 1933, EGP-TAM, Box 1, Emma Goldman Correspondence to Arthur Ross, Jan. 4, 1933-Dec. 30, 1933, 1.

128 Ibid. With regard to Germany, Goldman emphasized that "the German situation is more than a 'mess'. It is the most tragic event in centuries. A country of such high culture, of such thinkers, poets, writers and supreme musicians sunk deep into savagery, all its achievements thrust in the gutter, besmirched with blood.” Ibid., 2.

129 Emma Goldman, Dictatorship, Bolshevist and Fascist, n.d., EGP-IISH, No. 209, 1.

130 Hannah Arendt, The Origins of Totalitarianism (New York: Schocken, 1951); Carl Joachim Friedrich and Zbigniew K. Brzezinski, Totalitarian Dictatorship and Autocracy (Cambridge, MA: Harvard University Press, 1956). 
[T]hough the two dictatorships are of different origin and claim different aims, they are yet identical in their methods and in their effect upon the social, political and spiritual life of the people in the respective countries ... Out of the orgy of war. Out of two revolutions emerged the two newest political phenomena, the Left and the Right-Bolshevism and Fascism. Both are popular movements although fundamentally different in social origin and content. Both believe that force can perform miracles-that it can turn social misery into social paradise. ... Bolshevism began with Socialist and Communist revolutionary phrases. It promised freedom, iquality [sic!], bread. Instead it is developing Capitalism-State and private, with terror as its highest revolutionary deity ... Fascism began with National revolutionary phrases. ${ }^{131}$

For Goldman it was tragic, to say the least, that "[t]o the reactionary mind revolution is like a red rag to the bull [and that t]he reactionary conveniently forgets that whatever liberties he enjoys have come on the heels of revolution in his own country." ${ }^{132}$ Bolshevism was from Goldman's perspective no better than Fascism or National Socialism, as "Bolshevism far from being revolutionary has as a matter of fact crushed the Russian revolution, that is has gone back on its own revolutionary origin, and is fast becoming as reactionary as his European cousins." ${ }^{133}$ Yet in contrast, while Bolshevism had originated within the revolution, the other totalitarian regimes in the Europe of the 1930s had their origins in counter-revolutions. Nevertheless, Fascism was less dangerous for Goldman, as it was "composed of the riff raff thrown ashore by the backlash of the war, a murderous gang who never had ideals and never suffered for them." 134 Bolshevism under Lenin, and later Stalinism, were much more dangerous from an anarchist perspective, as too many workers and leftists believed that the Soviet Union actually represented their interests: "To maintain that in Russia the proletariat was ever the dictatorship is to perpetuate a delusion and a snare. From the very inception the Bolshevik dictatorship was over the proletariat and not of the proletariat. ... In Russia, the dictatorship has crushed the free Soviets, has embittered the peasantry, has eliminated the intellentsia [sic!], in fact, everyone who has helped to make the revolutions now fills the dread[f]ul Soviet prisons and former Tsarist places of exile." ${ }^{135}$

Goldman considered both forms of dicatorship to be the "Fetishes of our time, ${ }^{136}$ promising a world of order after years of chaos and violence, yet in re-

131 Goldman, Dictatorship, 1-2.

132 Ibid., 4.

133 Ibid., 5.

134 Ibid., 7.

135 Ibid., 10, 14.

136 Emma Goldman, Fascism and Dictatorship, n.d., EGP-IISH, No. 209, 1. 
ality their rule was as bad as that of their autocratic predecessors. What was different were the intellectual capacities of the leaders. While fascist leaders, according to Goldman, were far from smart-similar things could be said here about present-day fascists, no matter if they are American, Brazilian, British, German, or otherwise in origin-, "Lenin the creator of the Bolshevist dictatorship towered mountain high intellectually and spiritually over the pigmies that have infested numerous countries with [f]ascism."137 She continued her evaluation by emphasizing that "Hitler ... had never had a single solitary idea for human betterment, nor had he ever suffered for it. A Bully and a brute he knows how to play on the lowest traits in mass psychology. Neither he nor Mussolini could lace Lenin's boots." 138 All in all, Goldman argued that Bolshevism, Fascism, and National Socialism "in theory can not be compared, in methods unfortunately they meet, and have an identical effect upon the peoples who are coerced into [submission] to their respective regime."139

Considering the rise of Hitler, the "Tragedy of Germany,"140 Goldman held the SPD (Social Democratic Party) and the KPD (Communist Party) to be responsible. The former

accepted the Republic. But they did nothing to direct its course in constructive channels that would have helped to realize, if not all their programme had proclaimed for the workers, at least part of it. True they had helped to frame the Weimar Constitution, and then forgot all about it the moment it had been safely tucked away in the holy shrine of the state. ... [I]t is safe to say that the workers would not have been caught in the end had they not being misled by their own leaders. Had they not seen every effort at revolutionary resistance checked and declined in the Party Press as provocations [which] the workers should have nothing to do with. And finally had they not witnessed guns directed by Noske against their own comrades in the Spartacist uprising. The world knows only of the outstanding personalities who had lost their lives in a brave attempt to stem the tide of Hitlerism. It knows only of the tragic end of Rosa Luxemburg, [Karl] Liebknecht, [Gustav] Landauer, [Matthias] Erzberger, [Kurt] Eisner and [Walther] Rathenau. ${ }^{141}$

137 Ibid., 4.

138 Ibid., 5. Goldman would say in another lecture that Hitler, who was "obsessed by the Arian hallucination, is himself a 'mongrel mixture' of various non-German nationalities.” Emma Goldman, Hitler, n.d., EGP-IISH, No. 209, 1. In contrast to Italian Fascism, German National Socialism, for Goldman, seemed to be more barbaric and violent. Emma Goldman, Hitler and His Cohorts - Their World Menace, Draft, n.d., EGP-IISH, No. 265, 1.

139 Goldman, Fascism and Dictatorship, 5.

140 Emma Goldman, The Tragedy of Germany and the Forces that Caused It, Draft, n.d., EGPIISH, No. 265.

141 Ibid., 6, 12. 
The KPD, Goldman continued, "can also not be exempt from the doubtful honor of having added their sauce to the Nazi stew,"142 especially since they had been internally weakened by struggles with Moscow. The Bolshevist interpretation of the Russian Revolution and the realities it had created in Soviet Russia, and later the Soviet Union, weakened the German left and prevented a united front against National Socialism. Since the German Revolution of 1918/19, the Damoclean sword of Bolshevism hung over the chances for a truly better Germany, whose revolution had also been betrayed and violently suppressed by new and old elites. $^{143}$

National Socialism had eventually succeeded in channeling the violent potential in Germany into a political movement and was probably as heavily based on the support of fanatics and the use of violence as Bolshevism had been in Soviet Russia. Goldman described it as follows:

\begin{abstract}
National Socialism is no respecter of persons, ideas, creed or race. It is an insatiable monster who thrives on human blood. Thousands of Gentile German Communists, Anarchists, Syndicalists, Socialists, Pacifists, Intellectuals of the highest type, workers of the best human material, in short everybody who can not or will not put their heads in the Hitler noose, sing that infamous Horst Wessel Song or Heil Hitler until they lose their voices, have [been] and are savagely beaten, tortured, subjected to the most sickening humiliations and [were] carried half dead to hideous concentration camps. ${ }^{144}$
\end{abstract}

The rise of Hitler in Germany, Mussolini in Italy, and Stalin in the Soviet Union made Goldman think further about dictatorship on a more theoretical level, and she prepared "some notes for a possible long lecture on this topic."145 Like revolutions, something Goldman omitted here with regard to their role for the possible erection of dictatorships, the latter "always appear at a time of storm and stress; that is to say, at a time when the people in general are disillusioned, miserable, and lacking hope of better things." ${ }^{146}$ Its success is based on the "longing for some ideal, however vague and misty," which "is intensified by the feeling of misery and disillusionment with the existing." ${ }^{147}$ Dictators like Napoleon (17691821) in France and later "Stalin, Mussolini and Hitler have all risen on the back of despair and disillusionment, at a time when the people, despoiled and duped by their old governments, were hungry for some deliverer, some savior to lend

142 Ibid., 14.

143 Jones, Am Anfang.

144 Goldman, The Tragedy of Germany, 16-17.

145 Emma Goldman, Notes on Stalin, Mussolini, Hitler, November 1935, EGP-IISH, No. 209.

146 Ibid., 1.

147 Ibid. Emphasis in the original. 
them out of their misery." 148 To rise, all of them had used some kind of idea, maybe even a system of ideas, i.e. an ideology, like Hitler had in Germany: "The new savior was clever enough to put the word Socialism on his banner to secure immediate following. He added Nationalisms to it to appeal to the traditional German spirit of being 'a people elect'. And he cemented the whole of it with Jew-baiting, the spirit of which had been cultivated in Germany for generations past."149

The 1930s consequently were far from easy as an observer, but they had been even worse for her from work- and income-related perspectives. She had had trouble with her US lecture tour, as she had traveled without a manager, and James B. Pond, who had prepared Goldman's tour at Pond Bureau, Inc., New York, had the impression that she was collecting money for her lectures without sending it back to his office. ${ }^{150}$ Pond argued that "I entrusted you to look after the money matters in order that we both might save money. The net result is that you have retained all the money received, and we have had neither money nor accounting. ... Everybody is telling you all the things they would have done for you. I have been on the firing line and I can tell you in pretty terse words what your friends think of you." ${ }^{151}$ He also emphasized what Goldman might have been struck by the most during her US tour, namely that her lectures were rather unsuccessful from a financial perspective. Yet Pond was not willing to take the heat for this failure:

I repeat another thing, when this tour started out you, yourself, spoke of Madison Square Garden. There wasn't a single person connected with your family or friends, but [you] thought Mecca Temple was the proper place. You all had the same feeling that I and every other showman had that you were going to draw large audiences. Now, because you have had two successful meetings, out of an otherwise consistent run of failures, you inform me that the reason for the whole debacle was myself. There was a whole lot deeper reason than that. If any of the people who have been associated with you in the past had told me in advance what you were telling me now, we would have handled everything differently. ${ }^{152}$

Had Goldman dreamed too big? Were the times of success over for the "anarchist queen"? The formerly famous anarchist was, of course, not willing to accept this.

148 Ibid., 2.

149 Ibid., 3.

150 James B. Pond to Emma Goldman, New York, March 30, 1934, EGP-TAM, Box 1, Emma Goldman Correspondence to Arthur Ross et al., Jan. 22, 1930-Jun. 12, 1939, 1.

151 Ibid., 1-2.

152 Ibid., 3. 
She provided an itemized list for her income of $\$ 478.10$, of which $\$ 238$ had already been sent as a check to Pond, and the rest she would keep for possible expenses. With regard to the failure of the tour, she again emphasized the high admission fees: "Your reason for presenting Emma Goldman was purely financial. I am not finding fault with that. I regret your disappointment even more than mine. Just the same, I wish I had insisted from the very beginning on the lowest possible admission fees. I am certain I would have drawn large crowds." 153 Regardless of her pride, Goldman was sad to leave the United States again after her tour was over and confessed to Rudolph Rocker: "Yes, I admit it will be extremely painful. Much more so than 15 years ago to leave America. Then I turned my face to Russia, and my hopes went high, but now I know that I will never be able to do any kind of real work in Europe. It is only here that I can find myself, and I am sure you will not take it as braggadocio when I tell you that I never was in better trim, and never did better work. The greater the tragedy that I could reach so few people."154 Financially it had been a waste of time, as "old Emma will leave America as poor in cash as she has arrived."155 In her own mind, it was the topics she was allowed to talk about, the high admission fees and the high rent for lecture venues that sabotaged the success of the tour, but Goldman did not realize that she had reached her nadir. The anarchist movement had decreased in numbers, the Russian Revolution was lying in the past, and, for many Americans, Goldman herself was nothing more than a relic from a time that had long been left behind. Instead of reflecting on these reasons, Goldman ultimately searched for somebody else to blame and even turned her voice against the anarchist movement in the United States as such:

\footnotetext{
Frankly, as far as our comrades are concerned, I could say that with an easy conscience, for in the last 15 years, most of them are the last to have made one step forward or who have done anything for our ideas. They stick in their own little groups with 25 opinions for a dozen people; they have remained as petty and cantankerous as I have known them in the early years of my development. My faith in Anarchism would be shattered indeed if I were to believe that these people will construct a new society. Even if they could, I would be the last one to want to live in it for it would be more unbearable than now. Besides, they do not move a fly, let alone anything on the structure of American life. But it is Anarchism itself which burns like a red, white flame in my soul and it is for this reason that
}

153 Emma Goldman to James B. Pond, Chicago, IL, April 2, 1934, EGP-TAM, Box 1, Emma Goldman Correspondence to Arthur Ross et al., Jan. 22, 1930-Jun. 12, 1939, 3.

154 Emma Goldman to Rudolph Rocker, Pittsburgh, PA, April 12, 1934, EGP-TAM, Box 1, Emma Goldman Correspondence to Doris Zhook et al., Dec. 24, 1926-Jul. 31, 1939.

155 Ibid., 2. 
I would rather die in exile and poverty than I would detract one iota from its beauty and its logic. ${ }^{156}$

Europe, however, seemed to offer Goldman little more than the sadness she felt in the United States in 1934. The rise of National Socialism had endangered anarchists in Germany as well, where they were suppressed or worse, like the German anarchist Erich Mühsam (1878-1934), who "was among the first victims of the Nazi beasts, was subjected to the most terrible tortures and indignities and was finally strangled by the fiends." ${ }^{157}$ Goldman had to witness another system that would turn against her friends, but the survival of the Russian abyss did not suffice to gain a better and secure life for herself either.

In 1936, Goldman was alarmed by Berkman's suicide due to prostate cancer on 28 June, only a few weeks before the Spanish Civil War began. ${ }^{158}$ His death was a "shattering blow," and Goldman lost all hope: "The raison d'etre of my life is gone. What matters all else?" ${ }^{159}$ Now, the anarchist was truly alone. She had been isolated for a long time, but at least Berkman had been there as a steady support, an intellectual companion, and a true friend. Without him, Goldman was lost, and if Spain had not offered her a new task, she might not have survived her melancholic state any longer. The Spanish Civil War could have been the last chance for a new order that would follow anarchist ideas. This revitalized Goldman once more, who had already spent close to 15 years telling people the truth about Bolshevism. Nobody had listened. She had written about her life. Nobody wanted to read about it. She had talked about the similarities between Bolshevism and fascism. Nobody had listened. She had attempted to reawaken the American workers' movement by her presence during her lecture tour in the United States. Nobody had listened. And without Berkman, nobody would ever listen again. There was Spain now, but it would be another tragedy for her that the events between 1936 and 1939 could not correct the events between 1917 and 1936. For Goldman, living her life remained quite a tragic affair, and probably the greatest failure, from her perspective, was that the world was not only having to live with the consequences of the corruption of

156 Emma Goldman to Jeanne Levey, New York, April 23, 1934, EGP-TAM, Box 1, Emma Goldman Correspondence to Doris Zhook et al., Dec. 24, 1926-Jul. 31, 1939, 1.

157 Emma Goldman to Doris Zhook, Toronto, August 21, 1934, EGP-TAM, Box 1, Emma Goldman Correspondence to Doris Zhook et al., Dec. 24, 1926-Jul. 31, 1939.

158 Emma Goldman to Doris Zhook, St. Tropez, July 17, 1936, EGP-TAM, Box 1, Emma Goldman Correspondence to Doris Zhook et al., Dec. 24, 1926-Jul. 31, 1939.

159 Emma Goldman to Doris Zhook, St. Tropez, August 8, 1936, EGP-TAM, Box 1, Emma Goldman Correspondence to Doris Zhook et al., Dec. 24, 1926-Jul. 31, 1939, 1-2. 
the Russian Revolution by Lenin, it was now also witnessing an even worse dictatorship under Stalin. Goldman could not defeat a state, she could not defeat a government, and neither in the United States nor in the Soviet Union was she successful. Maybe the sun of Spain would see an old anarchist's dream finally come true. 
